\title{
Experience in a rehabilitation center for mastectomized women at the start of the COVID-19 pandemic
}

\author{
Experiencia en centro de rehabilitación de mujeres \\ mastectomizadas al inicio de la pandemia por COVID-19 \\ Experiência em centro de reabilitação de mulheres \\ mastectomizadas no início da pandemia do COVID-19
}

\author{
Rocío Zúñiga-Tapiaa \\ Marislei Sanches Panobianco ${ }^{b}$ \\ Maria Antonieta Spinoso Prado ${ }^{b}$ \\ Patricia Cid Henríquez ${ }^{c}$
}

\section{How to cite this article:} Zúniiga-Tapia R, Panobianco MS, Prado MAS, Cid Henríquez P. Experience in a rehabilitation center for mastectomized women at the start of the COVID-19 pandemic. Rev Gaúcha Enferm. 2021;42(spe):e20200331. doi: https://doi.org/10.1590/19831447.2021.20200331

\footnotetext{
Universidad de Concepción (UDEC), Estudiante Programa Magíster en Enfermería, Facultad de Enfermería. Concepción, Región del Biobío, Chile.

b Universidade de São Paulo (USP). Escola de Enfermagem de Ribeirão Preto, Departamento de Enfermagem Materno-Infantil e Saúde Pública. Ribeirao Preto, São Paulo, Brasil.

'Universidad de Concepción (UDEC), Facultad de Enfermería, Departamento Fundamentos de Enfermería y Salud Pública. Concepción, Región del Biobío, Chile
}

\section{ABSTRACT}

Objective: Describe the experience lived in an interdisciplinary follow-up care center for mastectomized women at a public university in São Paulo during the beginning of the COVID-19 pandemic.

Method: Experience report on the health care provided in the health center for mastectomized women.

Results: The care was provided three times a week by an interdisciplinary health team. The mentioned areas that cover the women care in the center: Physical, Psychological, Social Support and Health Education.

Conclusions: The attention by an interdisciplinary team becomes prevalent in the care of mastectomized women, since cancer and its treatment produce various changes in women's lives in the short and long term, so follow-up and support must be biopsychosocial, covering all areas that may be affected, especially during the pandemic.

Keywords: Women's health. Breast neoplasms. Mastectomy. Comprehensive health care. Coronavirus infections.

\section{RESUMEN}

Objetivo: Describir la experiencia vivida en un centro de atención interdisciplinaria de seguimiento a mujeres mastectomizadas de una universidad pública de São Paulo durante el inicio de la pandemia de COVID-19.

Método: Relato de experiencia sobre las atenciones de salud brindadas en el centro de salud para mujeres mastectomizadas.

Resultados: Las atenciones fueron realizadas tres veces por semana por un equipo interdisciplinario de salud. Se mencionan las áreas que abarcan la atención de las mujeres en el centro: Acompañamiento físico, Psicológico, Social y la Educación en Salud.

Conclusión: La atención por un equipo interdisciplinario se torna imperante en el cuidado de mujeres mastectomizadas, ya que el cáncer y su tratamiento producen diversos cambios en la vida de la mujer, a corto y largo plazo, por lo que el seguimiento y acompañamiento debe ser biopsicosocial, abarcando todas las áreas que pueden verse afectadas, especialmente durante la pandemia. Palabras clave: Salud de la mujer. Neoplasias de la mama. Mastectomía. Atención integral de salud. Infecciones por coronavirus.

\section{RESUMO}

Objetivo: Descrever a experiência vivida em um centro de acompanhamento interdisciplinar de mulheres mastectomizadas de uma universidade pública de São Paulo durante o início da pandemia COVID-19.

Método: Relato de experiência sobre cuidados de saúde prestados no centro de saúde para mulheres mastectomizadas. Resultados: 0 s atendimentos foram realizados três vezes por semana por uma equipe interdisciplinar de saúde. São mencionadas as áreas que abrangem o atendimento à mulher no centro: Acompanhamento físico, psicológico, social e Educação em saúde.

Conclusão: A atenção por uma equipe interdisciplinar torna-se predominante no cuidado de mulheres mastectomizadas, pois 0 câncer e seu tratamento produzem diversas mudanças na vida das mulheres, a curto e longo prazo. Portanto o acompanhamento deve ser biopsicossocial, cobrindo todas as áreas que podem ser afetadas, especialmente durante a pandemia.

Palavras-chave: Saúde da mulher. Neoplasias da mama. Mastectomia. Assistência integral à saúde. Infecções por coronavirus. 


\section{口INTRODUCTION}

Breast cancer is a public health problem in the world, being the most prevalent cancer in women in developed and developing countries; However, the mortality from breast cancer in developed countries has decreased due to efforts at timely screening and effective treatments ${ }^{(1)}$.

As a central procedure for the treatment of breast cancer, along with chemotherapy and radiotherapy, is the mastectomy, which consists by the removal of the breast, generally associated with axillary emptying ${ }^{(1)}$. Depending on the number of lymph nodes removed, the woman may present lymphedema, a complication that occurs when, during the transport of the lymphatic system, fluids and proteins are not evacuated from the interstitial space, causing accumulation of these and subsequent edema, differences in elasticity and a increased risk of infections ${ }^{(2)}$. Lymphedema has no cure, therefore, it persists until the survival period of people diagnosed with breast cancer, causing discomfort and disability of the arm on the affected side. The practice of exercises after surgery is essential for the recovery of mobility, prevention of several degrees of muscle atrophy and in the same way reduce the appearance of lymphedema $a^{(3-4)}$.

The other area affected by mastectomy is mainly associated with being a woman, since this surgery can result in an immediate and often permanent physical sequela, with negative effects on the person diagnosed with breast cancer and their family, because according to the cultural approach breasts are a symbol of femininity and reproductive capacity, they are also related to the areas of sensuality and sexuality of women ${ }^{(2,5)}$. This surgery leaves a mark, sometimes indelible, so the support by health professionals is very important, providing care, containment and support both in the treatment period and in the follow-up.

The follow-up of users with cancer should focus on controlling possible side effects, detecting an episode of cancer recurrence early and providing continuity of care over time, focusing on the fact that the latter should be interdisciplinary in nature as proposed in Chile by the National Cancer Plan ${ }^{(6)}$.

This work aims to describe the experience lived in an interdisciplinary follow-up center for mastectomized women at a public university in São Paulo and the anticipated return to my country, due to the advance of the COVID-19 (new coronavirus) pandemic, in the midst of the international internship that gave me this experience.

\section{$\square$ METHOD}

Experience report of stay in an interdisciplinary follow-up care center for mastectomized women belonging to a university located in the state of São Paulo. The experience report constitutes a scientific narrative that synthesizes an experience and its context and can be used as a point of opening and critical analysis of a phenomenon ${ }^{(7)}$. In nursing, a scientifically based discipline focused on caring for the human being, it can be useful to create and deepen knowledge in its various areas of study. Living an internship experience in another country is an opportunity for personal and professional growth.

The objective of the stay was to know the approach to research in women with breast cancer developed by interdisciplinary health teams; observe and participate in individual and group therapies for a better understanding of health problems; stimulate the potentialities and abilities for the coping of women diagnosed with breast cancer and their survival; and establish scientific collaboration networks with the team.

During the stay attended, 97 women between the ages of 37 and 88 years old. The care team consisted by a nurse, four physical therapists, three psychologists, and undergraduate students: eight from nursing, four from physical therapy, and six from psychology. The organization of the center depended on the University's School of Nursing. In this way, I participated in group sessions on Monday, Wednesday, and Friday mornings, beginning with physiotherapy and then a group meeting to discuss relevant issues for them, ask questions and clarify doubts associated with health problems secondary to mastectomy and cancer treatment in general; meeting guided by the nurse in charge.

The activities took place in different environments; Physiotherapy was performed in the open air at the first hour in the morning with a duration of 1 hour, and the group conversation activity took place in a classroom belonging to the center; for its realization, the women formed in a circle so that everyone could see and hear each other, this activity also lasted one hour. While these activities were being carried out, individual nursing and physiotherapy care were simultaneously performed on the women according to their needs, mainly anthropometric measurements to know the status of lymphedema or for its prevention, a complication secondary to mastectomy that is recommended to work with exercises of upper extremity. 
The stay took place during the month of March 2020, a period in which the COVID-19 pandemic had started gradually in Brazil and later reached an exponential increase in cases and death caused by it( ${ }^{(8)}$.

\section{Q RESULTS}

This report is presented in three parts that refer to the areas that cover the care of the women attended in the center and that I could experience during the stay (Physical Support, Psychological Support, Social Support), in the same way there is a cross-sectional area that is part of the three above, which is Health Education.

\section{Physical support}

As previously mentioned, mastectomy leaves physical sequelae in women, as well as complications associated with it that last over time, therefore this area must formulate the action plan of the professionals who provide health services to this target group.

The activities, performed on Monday, Wednesday or Friday, began with physiotherapy, which was carried out outside the center, with a pleasant open-air environment due to the characteristic climate of the area. The main objective of the performed exercises was to reduce lymphedema, a characteristic complication associated with mastectomy and lymph node removal, and these exercises also helped to maintain mobility of the affected limbs. The exercise lasted for an hour and was guided by a physiotherapy professional as well as undergraduate and graduate students.

\section{Emotional support}

As soon as the exercise session was over, the women who wanted to participate could enter the group session, consisting of an hour of open conversation where the participating women could ask multiple questions about their situation, consult doubts about the treatment or related to contingency issues for their health.

During my stay, one of the most relevant episodes was witnessing the first experience of women in the group conversation session after being invited by other older members, it was at that moment where this activity made more sense for the visit. This private, intimate and at the same time shared instance was where I was able to observe the support and containment provided between them as well as by the professionals. The conversation was moderated by the nurse in charge, who began by greeting each one and mentioning that everything that would be discussed in that session was of a private nature and could only be discussed in that place, after which each one said their name aloud, and then to open the conversation.

Neither session was the same as the other, the conversation revolved around topics proposed by the group, many of the participants, depending on the turn of the conversation, could speak, cry, laugh, remain silent, and leave their consternation and fears giving way to a unique moment of calm when realizing that there are women who are experiencing the same process or who have already lived it previously.

\section{Social support}

The activities of the center and its creation formed a bridge for women with similar life experiences to meet and share their stories. In this area, a choral group was formed under the eaves of the center as a recreational activity, with weekly rehearsals to learn new songs, a recreational activity that was very enjoyable for them, through which they strengthened their relationships, and a warm and friendly atmosphere was perceived.

During my stay I was able to participate in the birthday of a member of the center and of this choral group, being able to see the ties formed between them outside the center and the activities that take place in it. I was able to understand the importance of this for women and the formation of friendships and more than that, a family, as most related.

\section{Health education}

The education was present in the areas previously mentioned. The participating health professionals in the center educated the women who attended, either in the area of physiotherapy, providing indications of the exercises they should do at home, along with the reason why they should be performed; psychologists working and educating to have better mental health and manage to face this process; and the nurse in charge, who continuously educated on contingency issues, such as the doubts that women had regarding the treatment itself and the process involved in being diagnosed with breast cancer. Likewise, all joined to give support in the face of anxiety experienced by women due to the context lived by the beginning of COVID-19 cases in the State; in this way, various sessions were held where they discussed the risks associated with being a person with cancer and being diagnosed with coronavirus, and the recommendations for the use of a mask and social distancing, as measures to prevent contagion. 


\section{Experience during the COVID-19 pandemic}

In the months prior to the start of the stay, specifically in late December 2019, several health centers in Wuhan, Hubei province, China reported groups of patients with pneumonia of unknown cause epidemiologically related to a wholesale seafood market ${ }^{(9)}$, starting its expansion in an accelerated way in that country, to later spread in different countries of Asia and other regions of the world. Latin America was exempt until February 25, 2020, when the Brazilian Ministry of Health confirmed the first case in the area, imported from Lombardy, Italy ${ }^{(8)}$. he accelerated form of contagion translated into a large number of cases and deaths caused the Covid-19 disease, an acute respiratory disease caused by the SARS-CoV-2 virus, to be classified as a public health emergency worldwide ${ }^{(10)}$.

The group sessions in which I participated prior to the suspension of face-to-face activities at the university, the reason for the pandemic, were very useful to give support to the women participating in the group, and provide answers to their questions in relation to how to face the pandemic and associated risks, which are increased when undergoing cancer treatment or in remission of it ${ }^{(11)}$.

Unfortunately, the pandemic limited the length of stay and therefore the learning of this follow-up program for mastectomized women. Even so, ties were strengthened, and the teacher guides have continued to support the development of my master's thesis in Chile. I value the humanized work that is performed with the people who come to this center, highlighting the importance of nursing work in a care process that ranges from the person to their families, even in the period of pandemic.

Some time after the start of the pandemic, the center reorganized the activities developed, adapting them online to reduce the risk of infection for women, this is how weekly sessions of physiotherapy, group therapy and meetings on relevant issues are held during the contingency, maintaining the continuity of care. With individual attention when requested by women.

\section{QCONCLUSIONS}

The stay had to end early, due to the increase in people diagnosed with COVID-19, in the State of São Paulo, Brazil. However, the weeks that I was able to share with the women at the center helped me understand the importance of interdisciplinary support for mastectomized women, since as human beings we are complex beings who not only need health care for any physical discomfort, but also for our psychosocial needs; especially in this complex period.
During the stay, I was able to hear various reports of women with a long-term diagnosis of cancer as well as some who were in a post-surgery treatment period, who referred to the importance that the center had for their lives; some mentioned attending more than 20 years ago, which supported the fundamental role that it had for their development as a woman, contributing to the aforementioned edges for their family and social development.

The center faced the difficulties presented by the pandemic, providing continuity of care in order to continue achieving its proposed objective of providing comprehensive assistance to women with breast cancer and their families, stimulating their roles and abilities, within their social context.

\section{REFERENCES}

1. Ministerio de Salud (CL). Guías Clínicas AUGE: Cáncer de mama, Santiago: Minsal; 2015 [citado 2020 Mar 28]. Available from: https://www.minsal.cl/ wp-content/uploads/2015/09/GPC-CaMama.pdf

2. Ministerio de Salud (CL). Programa Adulto de drogas antineoplásicas PANDA. Santiago; 2007.

3. Pereira N, Isao K. Linfedema: actualización en el diagnóstico y tratamiento quirúrgico. Rev Chil Cir. 2018;70(6):589-97. doi: https://doi.org/10.4067/ s0718-40262018000600589

4. Kovacs D, De Almeida V, Louzada E, Rivero M. Adesão à prática de exercícios para reabilitação funcional de mulheres com câncer de mama: revisão de literatura. Cienc Enferm. 2010;16(1): 97-104. doi: https://doi.org/10.4067/ S0717-95532010000100011

5. Martínez-Basurto A, Lozano-Arrazola A, Rodríguez-Velázquez A, Galindo-Vázquez 0, Alvarado-Aguilar S. Impacto psicológico del cáncer de mama y la mastectomía. Gaceta Mex Oncol. 2014 [cited 2020 Apr 03];13(1):53-8. Available from: https://www.elsevier.es/ es-revista-gaceta-mexicana-oncologia-305-pdf-X1665920114278797

6. Ministerio de Salud (CL). Plan Nacional del Cáncer 2018-2028. Santiago, Minsal; 2018 [cited 2020 Apr 03]. Available from: https://www.minsal.cl/wp-content/ uploads/2019/01/2019.01.23_PLAN-NACIONAL-DE-CANCER_web.pdf

7. Daltro MR, Faria AA. Relato de experiência: uma narrativa científica na pósmodernidade. Estud Pesqui Psicol. 2019 [cited 2020 Apr 10];19(1):223-37. Available from: https://www.e-publicacoes.uerj.br/index.php/revispsi/article/ view/43015/29664

8. Rodriguez-Morales AJ, Gallego V, Escalera-Antezana JP, Méndez CA, Zambrano LI, Franco-Paredes C, et al. COVID-19 in Latin America: the implications of the first confirmed case in Brazil. Travel Med Infect Dis. 2020;35:101613. doi: https://doi.org/10.1016/j.tmaid.2020.101613

9. Zhu N, Zhang D, Wang W, Li X, Yang B, Song J, et al. A novel coronavirus from patients with pneumonia in China, 2019. N Engl J Med. 2020;38 (8):727-33. doi: https://doi.org/10.1056/NEJMoa2001017

10. Palacios M, Santos E, Velázquez MA, León M. COVID-19, una emergencia de salud pública mundial. Rev Clin Esp. 2020. Article in Press. doi: https://doi. org/10.1016/j.rce.2020.03.001

11. Moujaess E, Kouri HR, Ghosn M. Cancer patients and research during COVID-19 pandemic: a systematic review of current evidence. Crit Rev Oncol/Hematol. 2020:150102972. doi: https://doi.org/10.1016/j.critrevonc.2020.102972 


\section{- Acknowledgments:}

To the Universidade de São Paulo, for its dedication to the training of professionals. To the Universidad de Concepción, the Postgraduate Department and the Nursing Master's Program specifically, which gave me the opportunity to deepen my knowledge in my area of study, always promoting the continuous search for knowledge.

\section{- Authorship contribution:}

Conceptualization: Rocío Zúñiga-Tapia.

Funding acquisition: Rocío Zúñiga-Tapia; Patricia Cid Henríquez.

Investigation: Rocío Zúñiga-Tapia.

Methodology: Rocío Zúñiga-Tapia; Marislei Sanches Panobianco.

Project administration: Rocío Zúñiga-Tapia; Marislei Sanches Panobianco; Maria Antonieta Spinoso Prado.

Resources: Rocío Zúñiga-Tapia; Marislei Sanches Panobianco; Maria Antonieta Spinoso Prado; Patricia Cid Henríquez.

Supervision: Rocío Zúñiga-Tapia; Marislei Sanches Panobianco; Maria Antonieta Spinoso Prado; Patricia Cid Henríquez.

Supervision: Rocío Zúñiga-Tapia.

Writing-original draft: Rocío Zúñiga-Tapia.

Writing-review \& editing: Rocío Zúñiga-Tapia; Marislei Sanches Panobianco; Maria Antonieta Spinoso Prado; Patricia Cid Henríquez.

\section{- Corresponding author:}

Rocío Zúñiga-Tapia

Email: rozunigat@udec.cl

\section{Editor-in-chief:}

Maria da Graça Oliveira Crossetti 